\title{
Hemophagocytic lymphohistiocytosis with recurrent Kikuchi-Fujimoto disease
}

\author{
Sang Min Lee ${ }^{1}$, Young Tae Lim ${ }^{1}$, Kyung Mi Jang ${ }^{2}$, Mi Jin Gu ${ }^{3}$, Jong Ho Lee ${ }^{4}$, Jae Min Lee \\ ${ }^{1}$ Department of Pediatrics, Yeungnam University Hospital, Daegu, Korea \\ ${ }^{2}$ Department of Pediatrics, Yeungnam University College of Medicine, Daegu, Korea \\ ${ }^{3}$ Department of Pathology, Yeungnam University College of Medicine, Daegu, Korea \\ ${ }^{4}$ Department of Laboratory Medicine, Yeungnam University College of Medicine, Daegu, Korea
}

Received: July 17, 2020

Revised: September 2, 2020

Accepted: September 14, 2020

Corresponding author: Jae Min Lee, MD, PhD

Department of Pediatrics, Yeungnam University College of Medicine, 170 Hyeonchung-ro, Nam-gu, Daegu 42415, Korea

Tel: +82-53-620-3536

E-mail:mopic@yu.ac.kr
Kikuchi-Fujimoto disease (KFD), also known as histiocytic necrotizing lymphadenitis, is a self-limiting lymphadenitis. It is a benign disease mainly characterized by high fever, lymph node swelling, and leukopenia. Hemophagocytic lymphohistiocytosis $(\mathrm{HLH})$ is a life-threatening disease with clinical symptoms similar to those of KFD, but it requires a significantly more aggressive treatment. A 19-year-old Korean male patient was hospitalized for fever and cervical lymphadenopathy. Variable-sized lymph node enlargements with slightly necrotic lesions were detected on computed tomography. Biopsy specimen from a cervical lymph node showed necrotizing lymphadenitis with $\mathrm{HLH}$. Bone marrow aspiration showed hemophagocytic histiocytosis. The clinical symptoms and the results of the laboratory test and bone marrow aspiration met the diagnostic criteria for $\mathrm{HLH}$. The patient was diagnosed with macrophage activation syndrome- $\mathrm{HLH}$, a secondary HLH associated with KFD. He was treated with dexamethasone $\left(10 \mathrm{mg} / \mathrm{m}^{2} /\right.$ day $)$ without immunosuppressive therapy or etoposide-based chemotherapy. The fever disappeared within a day, and other symptoms such as lymphadenopathy, ascites, and pleural effusion improved. Dexamethasone was reduced from day 2 of hospitalization and was tapered over 8 weeks. The patient was discharged on day 6 with continuation of dexamethasone. The patient had no recurrence at the 18-month follow-up.

Keywords: Hemophagocytic lymphohistiocytosis; Kikuchi-Fujimoto disease; Necrotizing lymphadenitis

\section{Introduction}

Kikuchi-Fujimoto disease (KFD), also known as histiocytic necrotizing lymphadenitis, is a self-limiting lymphadenitis. Its symptoms mainly include high fever, lymph node swelling, and leukopenia [1]. The etiology of KFD is unclear, and KFD is presumed to be preceded by infectious or autoimmune diseases, although this has not been confirmed [2]. Treatment is symptomatic with nonsteroidal anti-inflammatory drugs, and most symptoms improve within a few months [2]. Hemophagocytic lymphohistio- cytosis (HLH) is a life-threatening disease with clinical symptoms similar to those of KFS. Severe systemic hyperinflammation requires a markedly more aggressive treatment than that required for KFD. Only a few cases have been reported for both diseases. We herein report a case of HLH associated with KFD in a 19-year-old male patient who was admitted with fever and cervical lymphadenopathy and was successfully treated with corticosteroids. 


\section{Case}

A 19-year-old male patient presented with high fever and neck swelling for 5 weeks. The patient was treated with amoxicillin-clavulanate, ceftriaxone, and dexamethasone ( $5 \mathrm{mg} /$ day) for 9 days at the local medical center (LMC), but his condition did not improve. The patient had experienced KFD 3 years earlier with symptoms such as fever, cervical lymphadenitis, and joint pain. In the laboratory tests, no specific findings, except elevation in the C-reactive protein (CRP) levels and erythrocyte sedimentation rate (ESR), were noted. Lymph node enlargement and slightly necrotic lesions were observed in the neck computed tomography (CT) scan. Analysis of the core needle biopsy specimen indicated histiocytic necrotizing lymphadenitis, which was observed in KFD. The patient had a steroid dependency and was treated with hydroxychloroquine [3].

Physical examination revealed painful cervical lymph node enlargement and tonsillar swelling on both sides. Variable-sized lymph node enlargements with slightly necrotic lesions were detected on CT (Fig. 1A). A small amount of bilateral pleural effusion and multiple infiltrative enlarged lymph nodes in the anterior mediastinum were observed (Fig. 1B). Mild hepatomegaly and segmental wall thickening of the gallbladder were also noted.

Laboratory findings were as follows: white blood cell count, $2,060 / \mu \mathrm{L}$ (54.9\% neutrophils); absolute neutrophil count, 1,130/ $\mu \mathrm{L}$; hemoglobin level, $11.8 \mathrm{~g} / \mathrm{dL}$; platelet count, $145,000 / \mu \mathrm{L}$; aspartate aminotransferase, $275 \mathrm{IU} / \mathrm{L}$; alanine aminotransferase, 164 $\mathrm{IU} / \mathrm{L}$; and $\gamma$-glutamyl transferase, $916 \mathrm{IU} / \mathrm{L}$. Other laboratory findings were as follows: elevated CRP level, $7.417 \mathrm{mg} / \mathrm{dL}$ (range, $<0.5 \mathrm{mg} / \mathrm{dL}$ ); ESR, $32 \mathrm{~mm} / \mathrm{hr}$ (range, $0-20 \mathrm{~mm} / \mathrm{hr}$ ); elevated procalcitonin level, $16.2 \mathrm{ng} / \mathrm{mL}$ (range, $0-0.5 \mathrm{ng} / \mathrm{mL}$ ); elevated serum ferritin level, 19,640.61 ng/mL (range, 29-278 ng/mL); elevated fasting triglyceride level, $372 \mathrm{mg} / \mathrm{dL}$ (range, $35-160 \mathrm{mg}$ / $\mathrm{dL}$ ); fibrinogen level, $229 \mathrm{mg} / \mathrm{dL}$ (range, 200-400 mg/dL); elevated soluble CD25 (sIL-2 receptor) level, 2,817 U/mL (range, $158-623 \mathrm{U} / \mathrm{mL}$ ); natural killer cell activity, $>2,000 \mathrm{pg} / \mathrm{mL}$ (range, $>500 \mathrm{pg} / \mathrm{mL}$ ); C3 level, $99.6 \mathrm{mg} / \mathrm{dL}$ (range, $83-177 \mathrm{mg}$ / $\mathrm{dL}$ ); C4 level, $43.6 \mathrm{mg} / \mathrm{dL}$ (range, 15-45 mg/dL); CH50 level, 55 $\mathrm{U} / \mathrm{mL}$ (range, $75-160 \mathrm{U} / \mathrm{mL}$ ); antinuclear antibody, negative; cytomegalovirus immunoglobulin ( $\mathrm{Ig}$ ) M, negative; and Epstein-Barr virus IgM and polymerase chain reaction, negative. $\mathrm{He}$ was initially treated with vancomycin, meropenem, and metronidazole. However, he did not respond to antibiotic treatment, and the fever persisted. Core needle biopsy specimen from the cervical lymph node and bone marrow aspiration and biopsy were performed on hospitalization day 3. The cervical lymph node biopsy showed necrotizing lymphadenitis with HLH (Fig. 2). Bone marrow aspiration and biopsy showed normocellular marrow with increased hemophagocytic histiocytosis (Fig. 3). The patient met the five diagnostic criteria for HLH. Thus, he was diagnosed with secondary HLH associated with KFD.

The patient initiated treatment with intravenous dexamethasone $\left(10 \mathrm{mg} / \mathrm{m}^{2} /\right.$ day $)$. The fever disappeared in a day, and other symptoms such as lymphadenopathy, ascites, and pleural effusion improved. Dexamethasone was reduced from day 2 and was tapered over 8 weeks. The patient was discharged on day 6 with continuation of dexamethasone. He was followed up at the outpatient clinic and had no recurrence at the 18 -month follow-up. Next-generation sequencing was performed to determine any genetic abnormalities related to HLH, but no such abnormalities were found.
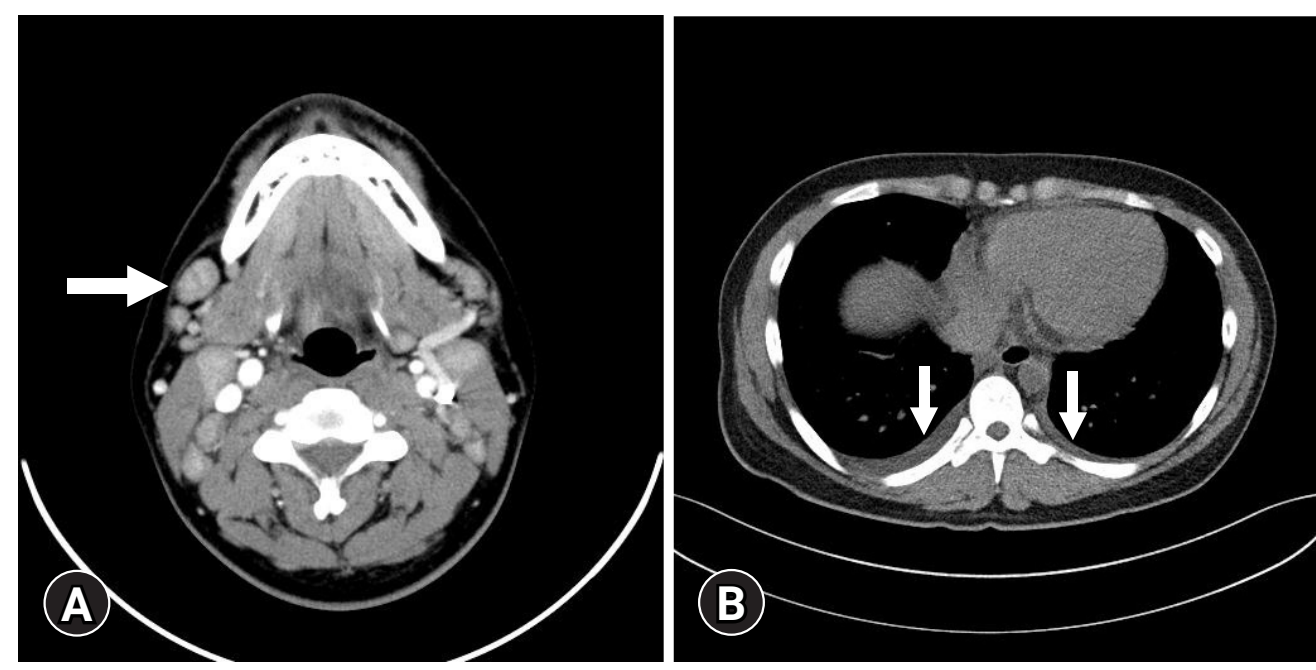

Fig. 1. (A) Neck computed tomography (CT) shows scattered, variable-sized lymph node enlargements (arrow) on both neck at levels I to IV. (B) Chest CT shows a small amount of bilateral pleural effusion (arrows). 


\section{Discussion}

KFD is a benign disease mainly characterized by high fever, lymph node swelling, and leukopenia. It usually develops in young adults aged less than 30 years and is confirmed by biopsy with histological findings of histiocytic necrotizing lymphadenitis [1]. KFD usually requires no special treatment. However, when systemic symptoms are severe or accompanied by an autoimmune disease, steroid treatment should be considered [1].

HLH is a syndrome that manifests in patients with severe systemic hyperinflammation. The typical findings of HLH include fever, hepatosplenomegaly, and cytopenia. Other common findings include hypertriglyceridemia, coagulopathy with hypofibrinogenemia, liver dysfunction, and elevated levels of ferritin and serum

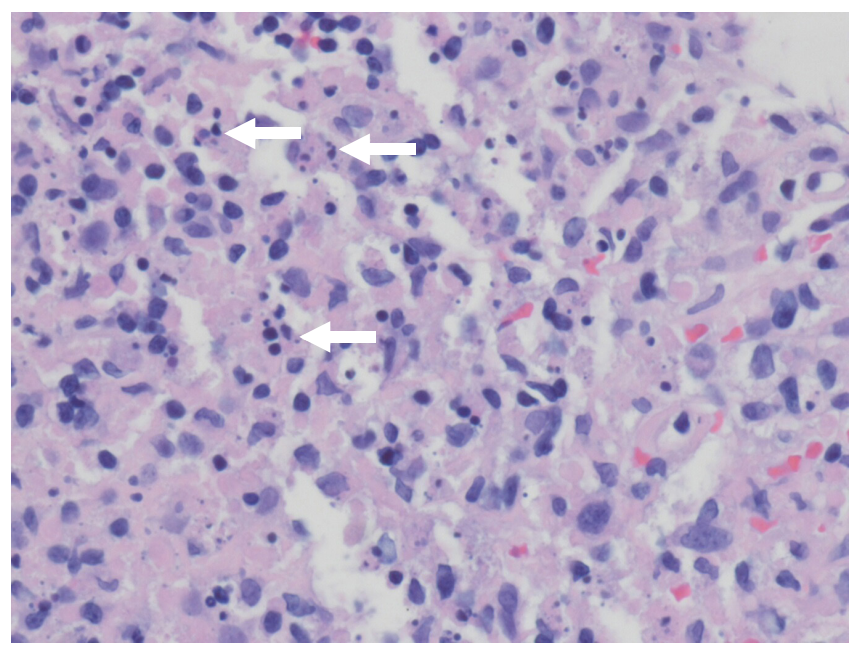

Fig. 2. Histological findings of the cervical lymph node. The biopsy specimen shows necrotizing lymphadenitis with karyorrhectic nuclear debris (arrows) (hematoxylin and eosin stain, $\times 400$ ). transaminases. Other, less common, initial clinical findings include lymphadenopathy, skin rash, jaundice, and edema. Primary HLH occurs because of a genetic abnormality or is idiopathic, but secondary HLH is known to be caused by strong activation of the immune system, in most cases, because of severe infections and is mainly caused by immunosuppression. However, it can also occur in malignancy and rheumatologic conditions [4]. HLH has early symptoms similar to KFD but requires active treatment and has a poor prognosis.

We report a case of secondary HLH caused by recurrent KFD. Until now, fewer than 20 cases of HLH with KFD have been reported (Table 1) [5-18]. According to the literature review, the average age of patients was $17.5 \pm 11.6$ years, and this disease affected 12 male patients (63.2\%) and seven female patients (36.8\%). The incidence rates by country were as follows: Korea, $47.4 \%(n=9)$; Japan, 15.8\% ( $\mathrm{n}=3)$; Taiwan, 15.8\% $(\mathrm{n}=3)$; United Kingdom, 5.3\% ( $\mathrm{n}=1)$; United States, 5.3\% $(\mathrm{n}=1)$; Qatar, 5.3\% $(\mathrm{n}=1)$; and Thailand, 5.3\% ( $n=1)$. In terms of race, 18 out of 19 patients were Asian, accounting for $94.7 \%$ of patients. The most common symptoms were fever (100\%) and lymphadenopathy (89.5\%), followed by seizure, fatigue, and erythema. The medications administered in the reports were steroid (68.4\%), intravenous $\operatorname{Ig}(36.8 \%)$, etoposide (21.1\%), and cyclosporine A (10.5\%). In terms of outcomes, 17 of the patients $(89.5 \%)$ had complete remission, whereas two patients (10.5\%) died. HLH with KFD has a relatively good prognosis and response to treatment, but its diagnosis and standard treatment have not yet been established.

The manifestation of HLH symptoms in patients with rheumatic conditions is called macrophage activation syndrome (MAS). From the revised classification in 2016, the term MAS-HLH has been suggested. Among patients with secondary HLH, those with
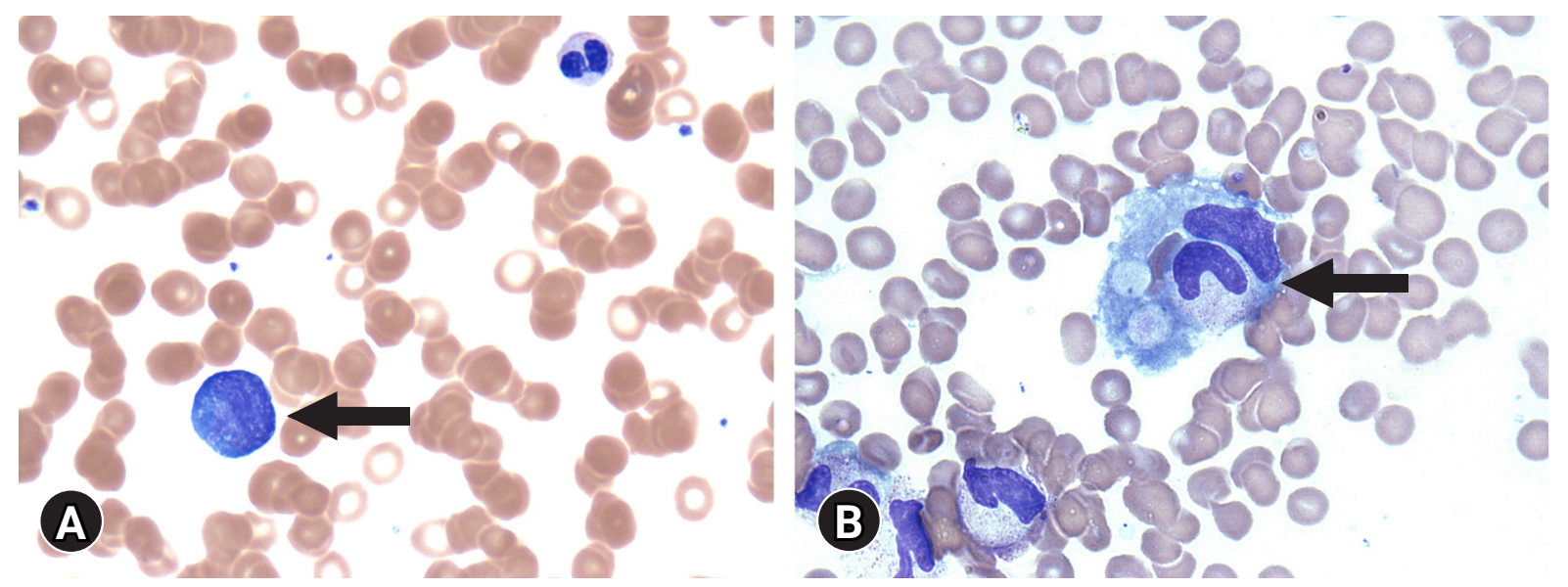

Fig. 3. (A) Peripheral blood smear shows atypical lymphocytes (arrow) (Wright's stain, $x 1,000$ ). (B) Bone marrow aspirate smear shows hemophagocytic histiocytes (arrow) engulfing granulocytes and red blood cells (Wright's stain, x1,000). 
Table 1. Clinical characteristics, treatment, and outcome of Kikuchi-Fujimoto disease-associated hemophagocytic lymphohistiocytosis

\begin{tabular}{|c|c|c|c|c|c|c|c|c|c|c|}
\hline Year & Study & $\begin{array}{c}\text { No. of } \\
\text { patients }\end{array}$ & Age (yr) & Sex & Country & Race & Symptom & Treatment & Outcome & Remark \\
\hline \multirow[t]{2}{*}{2000} & Chen et al. [5] & 2 & 14 & M & Taiwan & Asian & $\begin{array}{l}\text { Fever, fatigue, cervical } \\
\text { lymph node swelling }\end{array}$ & IVIG & $\mathrm{CR}$ & NA \\
\hline & & & 10 & $\mathrm{~F}$ & Taiwan & Asian & $\begin{array}{l}\text { Fever, cervical lymph } \\
\text { node swelling }\end{array}$ & Steroid, IVIG & $\mathrm{CR}$ & NA \\
\hline 2000 & Kelly et al. [6] & 1 & 17 & $\mathrm{~F}$ & $\begin{array}{l}\text { United } \\
\text { Kingdom }\end{array}$ & Asian & $\begin{array}{l}\text { Fever, cervical } \\
\text { lymphadenopathy }\end{array}$ & IVIG & $\mathrm{CR}$ & NA \\
\hline 2003 & Kim et al. [7] & 1 & 13 & $\mathrm{~F}$ & Korea & Asian & $\begin{array}{l}\text { Fever, seizure, cervical } \\
\text { lymph node swelling }\end{array}$ & Steroid, IVIG & $\mathrm{CR}$ & NA \\
\hline 2007 & Lin et al. [8] & 1 & 13 & M & Japan & Asian & $\begin{array}{l}\text { Fever, axillary and inguinal } \\
\text { lymphadenopathy }\end{array}$ & Steroid & CR & NA \\
\hline 2007 & Khan et al. [9] & 1 & 40 & M & Qatar & Asian & $\begin{array}{l}\text { Fever, cervical } \\
\text { lymphadenopathy }\end{array}$ & NSAIDs & $\mathrm{CR}$ & NA \\
\hline \multirow[t]{5}{*}{2008} & Lim et al. [10] & 5 & 12 & M & Korea & Asian & $\begin{array}{l}\text { Fever, cervical } \\
\text { lymphadenopathy }\end{array}$ & Steroid & $\mathrm{CR}$ & Recurred after $2 \mathrm{yr}$ \\
\hline & & & 14 & M & Korea & Asian & $\begin{array}{l}\text { Fever, multiple } \\
\text { lymphadenopathy }\end{array}$ & $\begin{array}{l}\text { Steroid, IVIG, } \\
\text { ACV, VP16 }\end{array}$ & $\mathrm{CR}$ & EBV, recurred after $7 \mathrm{yr}$ \\
\hline & & & 5 & $\mathrm{~F}$ & Korea & Asian & $\begin{array}{l}\text { Fever, multiple } \\
\text { lymphadenopathy }\end{array}$ & Steroid, VP16 & $N R$, died & NA \\
\hline & & & 14 & $\mathrm{~F}$ & Korea & Asian & $\begin{array}{l}\text { Fever, cervical } \\
\text { lymphadenopathy }\end{array}$ & $\begin{array}{l}\text { Steroid, IVIG, } \\
\text { VP16, CyA }\end{array}$ & $\mathrm{CR}$ & NA \\
\hline & & & 8 & M & Korea & Asian & $\begin{array}{l}\text { Fever, multiple } \\
\text { lymphadenopathy }\end{array}$ & Steroid & $\mathrm{CR}$ & EBV \\
\hline 2008 & Kampitak [11] & 1 & 50 & M & Thailand & Asian & $\begin{array}{l}\text { Fever, fatigue, myalgia, } \\
\text { multiple lymphadenop- } \\
\text { athy, seizure }\end{array}$ & $\begin{array}{l}\text { Steroid, immu- } \\
\text { nosuppressive } \\
\text { therapy }\end{array}$ & $N R$, died & SLE \\
\hline 2009 & Byoun et al. [12] & 1 & 21 & $\mathrm{~F}$ & Korea & Asian & $\begin{array}{l}\text { Fever, cervical } \\
\text { lymphadenopathy }\end{array}$ & Steroid, ACV & $\mathrm{CR}$ & EBV \\
\hline 2010 & Lee et al. [13] & 1 & 16 & M & Taiwan & Asian & $\begin{array}{l}\text { Fever, cervical and axillary } \\
\text { lymphadenopathy }\end{array}$ & Antibiotics & $\mathrm{CR}$ & EBV \\
\hline 2011 & Kim et al. [14] & 1 & 18 & M & Korea & Asian & $\begin{array}{l}\text { Fever, cervical } \\
\text { lymphadenopathy }\end{array}$ & $\begin{array}{l}\text { Steroid, IVIG, } \\
\text { VP16, CyA }\end{array}$ & $\mathrm{CR}$ & NA \\
\hline 2011 & Kim et al. [15] & 1 & 0.75 & M & Korea & Asian & $\begin{array}{l}\text { Fever, cervical } \\
\text { lymphadenopathy }\end{array}$ & Antibiotics & CR & NA \\
\hline 2013 & Koga et al. [16] & 1 & 21 & M & Japan & Asian & $\begin{array}{l}\text { Fever, cervical lymphade- } \\
\text { nopathy, erythema }\end{array}$ & Steroid & $\mathrm{CR}$ & Sweet's disease \\
\hline 2016 & Sykes et al. [17] & 1 & 16 & $\mathrm{~F}$ & $\begin{array}{l}\text { United } \\
\text { States }\end{array}$ & NA & Fever, joint pain, fatigue & Antibiotics & $\mathrm{CR}$ & NA \\
\hline 2016 & Nishiwaki et al. [18] & 1 & 30 & $M$ & Japan & Asian & Fever, sore throat & Steroid & $\mathrm{CR}$ & NA \\
\hline
\end{tabular}

M, male; F, female; IVIG, intravenous immunoglobulin; $C R$, complete remission; NA, not applicable; NSAIDs, nonsteroidal anti-inflammatory drugs; ACV, acyclovir; VP16, etoposide; EBV, Epstein-Barr virus; NR, no response; CyA, cyclosporine A; SLE, systemic lupus erythematosus.

associated rheumatic conditions are diagnosed with MAS-HLH [19]. In our case, the patient was diagnosed with HLH caused by KFD. As KFD is associated with rheumatic disease [2], HLH associated with KFD was regarded as MAS-HLH.

Currently, the standard therapy for HLH comprises dexamethasone and etoposide based on HLH-94 treatment protocol. The treatment of HLH should be accompanied by appropriate treatment of the identified underlying trigger [4]. Although the HLH94 protocol is required in most HLH patients, steroids with or without intravenous Ig may be sufficient for patients with less severe HLH or those with MAS-HLH [20]. Cases of successful treatment by steroid alone have been reported $[8,10,16,18]$. Our patient did not appear seriously ill, and the dose of steroid therapy at the LMC was inadequate. Therefore, we decided to administer an appropriate dose of steroid alone. He was followed up at the outpatient clinic and presented with no recurrence at the 18-month follow-up. MAS-HLH is an autoimmune disease associated with rheumatic conditions. Therefore, steroid treatment was considered appropriate as the underlying triggers were eliminated with steroid administration. In this case, we confirmed the effectiveness of steroid treatment alone for MAS-HLH. Therefore, it would be appropriate to classify secondary HLH associated with KFD as MAS-HLH and to treat it accordingly.

In conclusion, recurrent KFD has the possibility of progressing 
to HLH. HLH requires a more aggressive treatment than KFD. However, in the case of MAS-HLH, specifically KFD-associated HLH, treatment with steroids alone should be provided without the administration of immunosuppressive drugs such as etoposide or cyclosporine A.

\section{Notes}

\section{Ethical statements}

This report was approved by the Institutional Review Board (IRB) of the Yeungnam University Hospital (IRB No: YUMC 2020-07038). Written informed consent was obtained from the patient for the publication of this case report and the accompanying images.

\section{Conflicts of interest}

No potential conflict of interest relevant to this article was reported.

\section{Funding}

This work was supported by the 2019 Yeungnam University Research Grant (219A480007).

\section{Author contributions}

Conceptualization: all authors; Data curation: SML, YTL, KMJ, MJG, JHL; Formal analysis and Supervision: JML; Funding acquisition and Validation: JML; Methodology: SML, YTL, KMJ, MJG, JHL; Investigation: SML; Resources: YTL, KMJ, MJG, JHL; Writing-original draft: all authors; Writing-review \& editing: all authors.

\section{ORCID}

Sang Min Lee, https://orcid.org/0000-0002-6169-3504

Young Tae Lim, https://orcid.org/0000-0001-9926-0467

Kyung Mi Jang, https://orcid.org/0000-0002-2226-9268

Mi Jin Gu, https://orcid.org/0000-0002-8350-3038

Jong Ho Lee, https://orcid.org/0000-0002-6837-838X

Jae Min Lee, https://orcid.org/0000-0001-6822-1051

\section{References}

1. Bosch X, Guilabert A. Kikuchi-Fujimoto disease. Orphanet J Rare Dis 2006;1:18.

2. Deaver D, Horna P, Cualing H, Sokol L. Pathogenesis, diagnosis, and management of Kikuchi-Fujimoto disease. Cancer Control 2014;21:313-21.

3. Jang KM, Lee JM. A case of recurrent steroid-dependent Kikuchi-Fujimoto disease successfully treated with hydroxychloro- quine. Clin Pediatr Hematol Oncol 2017;24:144-7.

4. Henter JI, Horne A, Aricó M, Egeler RM, Filipovich AH, Imashuku S, et al. HLH-2004: diagnostic and therapeutic guidelines for hemophagocytic lymphohistiocytosis. Pediatr Blood Cancer 2007;48:124-31.

5. Chen JS, Chang KC, Cheng CN, Tsai WH, Su IJ. Childhood hemophagocytic syndrome associated with Kikuchi's disease. Haematologica 2000;85:998-1000.

6. Kelly J, Kelleher K, Khan MK, Rassam SM. A case of haemophagocytic syndrome and Kikuchi-Fujimoto disease occurring concurrently in a 17-year-old female. Int J Clin Pract 2000; 54:547-9.

7. Kim YM, Lee YJ, Nam SO, Park SE, Kim JY, Lee EY. Hemophagocytic syndrome associated with Kikuchi's disease. J Korean Med Sci 2003;18:592-4.

8. Lin YW, Horiuchi H, Ueda I, Nambu M. Recurrent hemophagocytic lymphohistiocytosis accompanied by Kikuchi's disease. Leuk Lymphoma 2007;48:2447-51.

9. Khan FY, Morad NA, Fawzy Z. Kikuchi's disease associated with hemophagocytosis. Chang Gung Med J 2007;30:370-3.

10. Lim GY, Cho B, Chung NG. Hemophagocytic lymphohistiocytosis preceded by Kikuchi disease in children. Pediatr Radiol 2008;38:756-61.

11. Kampitak T. Fatal Kikuchi-Fujimoto disease associated with SLE and hemophagocytic syndrome: a case report. Clin Rheumatol 2008;27:1073-5.

12. Byoun YS, Park BB, Song SH, Park SY, Chung SM, Lee JS, et al. A case of Kikuchi Fujimoto's disease accompanied by hemophagocytic lymphohistiocytosis. Korean J Hematol 2009; 44:325-9.

13. Lee HY, Huang YC, Lin TY, Huang JL, Yang CP, Hsueh T, et al. Primary Epstein-Barr virus infection associated with Kikuchi's disease and hemophagocytic lymphohistiocytosis: a case report and review of the literature. J Microbiol Immunol Infect 2010; 43:253-7.

14. Kim HJ, Park JY, Chung SM, Kim HS. A case of Kikuchi's disease associated with hemophagocytic syndrome. Korean J Otorhinolaryngol-Head Neck Surg 2011;54:859-61.

15. Kim HA, Im SA, Chung NG, Kang JH, Park GS. Disseminated Kikuchi disease associated with hemophagocytic syndrome in an infant: whole-body MRI. Indian J Pediatr 2011;78:616-9.

16. Koga T, Takano K, Horai Y, Yamasaki S, Nakamura H, Mizokami A, et al. Sweet's syndrome complicated by Kikuchi's disease and hemophagocytic syndrome which presented with retinoic acid-inducible gene-I in both the skin epidermal basal layer and the cervical lymph nodes. Intern Med 2013;52:1839-43.

17. Sykes JA, Badizadegan K, Gordon P, Sokol D, Escoto M, Ten I, 
et al. Simultaneous acquired self-limited hemophagocytic lymphohistiocytosis and Kikuchi necrotizing lymphadenitis in a 16-year-old teenage girl: a case report and review of the literature. Pediatr Emerg Care 2016;32:792-8.

18. Nishiwaki M, Hagiya H, Kamiya T. Kikuchi-Fujimoto disease complicated with reactive hemophagocytic lymphohistiocytosis. Acta Med Okayama 2016;70:383-8.

19. Emile JF, Abla O, Fraitag S, Horne A, Haroche J, Donadieu J, et al. Revised classification of histiocytoses and neoplasms of the macrophage-dendritic cell lineages. Blood 2016;127:2672-81.

20. Jordan MB, Allen CE, Greenberg J, Henry M, Hermiston ML, Kumar A, et al. Challenges in the diagnosis of hemophagocytic lymphohistiocytosis: recommendations from the North American Consortium for Histiocytosis (NACHO). Pediatr Blood Cancer 2019;66:e27929. 